YEARBOOK

of ANTITRUST

and REGULATORY

STUDIES

www.yars.wz.uw.edu.pl
Peer-reviewed scientific periodical, focusing on legal and economic issues of antitrust and regulation.

Creative Commons Attribution-No Derivative Works 3.0 Poland License.

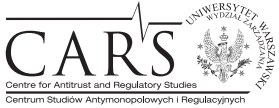

Centre for Antitrust and Regulatory Studies, University of Warsaw, Faculty of Management www.cars.wZ.uw.edu.pl

\title{
Georgia's First Steps in Competition Law Enforcement: The Role and Perspectives of the Private Enforcement Mechanism
}

\author{
by
}

Zurab Gvelesiani*

\section{CONTENTS}

I. Introduction

II. Evolution of Georgian competition law and its recent reforms

III. Necessity for private enforcement of competition law in Georgia

IV. Availability of private enforcement of competition law infringements and damages claims

V. Challenges for the development of an effective private enforcement system

VI. Conclusions

\section{Abstract}

The goal of this article is to assess the role and perspectives of the private enforcement of competition law mechanism in Georgia. The discussion starts with a brief review of a number of major events that have occurred in Georgia in the last two decades, which have shaped its competition law. The paper provides next an assessment of the current stage of the development of Georgian competition legislation, the necessity for a private enforcement model as well as the rules and legal tools offered by existing Georgian law in that regard. Outlined are also a number of challenges that must be overcome in order for Georgia to develop a successful and effective private enforcement system. The examination is based on a wide range of Georgian legislation; the interpretations provided are supported by existing enforcement practice, views of experts and scholars, research studies, reports and surveys from various national and international organizations.

*PhD candidate, Central European University, Budapest; Gvelesiani_Zurab@phd.ceu.edu. 


\section{Résumé}

Le but de cet article est d'évaluer le rôle et les perspectives de l'application privée du droit de la concurrence en Géorgie. Lanalyse commence par un bref examen d'un certain nombre de grands événements qui ont eu lieu en Géorgie dans les deux dernières décennies et qui ont façonné le droit de la concurrence géorgien. Ensuite, le document fournit une évaluation d'état actuelle du développement de la législation concernant le droit de la concurrence en Georgie, souligne la nécessité du développement d'un modèle d'application privée du droit de la concurrence, ainsi qu'entreprend une analyse des mécanismes d'application privée du droit de la concurrence disponibles actuellement dans la loi géorgienne. Larticle indique aussi un certain nombre de défis qui doivent être surmontés afin que la Géorgie puisse développer un système efficace d'application privée du droit de la concurrence. Lanalyse est basée sur une grande partie de la législation géorgienne. Les interprétations fournies sont soutenus par la pratique de l'application privée du droit de la concurrence en Georgie, par les opinions des experts et des chercheurs, ainsi que par les différentes études, rapports et enquêtes publiés par des diverses organisations nationales et internationales.

Key words: competition law; competition law infringement; damages; private enforcement; damage claims; Georgia; country specific challenges.

JEL: K23; K42.

\section{Introduction}

Georgia has a new Law on Competition ${ }^{1}$. It has also not been long since its new competition authority - the Competition Agency - was formed and started functioning. So far, there is no national jurisprudence or developed case law, therefore no special tendencies have yet been shaped in practice. Georgia does have, however, a distorted market with supposedly numerous victims of various competition law infringements. Private actors are finally offered a possibility to take direct action and claim damages. The article will discuss how practical the existing model is, and what are the perspectives, opportunities and challenges facing it in the future. In order to better demonstrate Georgia's current developmental stage, the following section explores the unique evolutionary path taken by Georgian competition law, which has shaped its modern national market. The paper provides an analysis of the need for the development of private enforcement in Georgia, and reviews existing legal

\footnotetext{
${ }^{1}$ Parliament of Georgia, Law of Georgia of 8 May 2012, No. 6148-Is on Competition.
} 
tools that allow private entities to take action and claim damages. Finally, it assesses the main barriers and challenges on the road of building an effective national private enforcement system. Due to size limitations, the final section of the paper focuses on the specific problems experienced by Georgia, omitting common hardships of private enforcers, which is subject to an extensively rich literature ${ }^{2}$.

\section{Evolution of Georgian competition law and its recent reforms}

Since 2003, Georgia has gone through a massive reformation process and attained a number of impressive achievements ${ }^{3}$. In certain fields, Georgia's success was so remarkable that it was used as a model to be 'exported' to other countries ${ }^{4}$. However, success has not been shared by the reforms of

2 See N. Bučan Gutta, The Enforcement of EU Competition Rules by Civil Law, AntwerpenApeldoorn-Portland 2014; A.P. Komninos, EC Private Antitrust Enforcement, Decentralised Application of EC Competition Law by National Courts, Oxford-Portland 2008; V. Milutinović, The 'Right to Damages' under EU Competition Law: from Courage v. Crehan to the White Paper and Beyond, Alphen aan den Rijn 2010; I. Van Bael, Due Process in EU Competition Proceedings, Alphen aan den Rijn 2011; J. Basedow, J.P. Terhechte, L. Tichý, Private Enforcement of Competition Law, Baden-Baden 2011; M. Berglund, Cross-Border Enforcement of Claims in the EU: History, Present Time and Future, Alphen aan den Rijn 2014; W.P.J. Wils, 'Should Private Antitrust Enforcement Be Encouraged in Europe?' (2003) 26(3) World Competition: Law and Economics Review; D.F. Engstrom, 'Private Enforcement's Pathways: Lessons from Qui Tam Litigation' (2014) 114(8) Columbia Law Review 1913-2006; T.M.J. Möllers, A. Heinemann, The Enforcement of Competition Law in Europe, Cambridge-New York 2007; M. Ioannidou, Consumer Involvement in Private EU Competition Law Enforcement, Oxford 2015; K.J. Cseres, J. Mendes, 'Consumers' access to EU competition law procedures: outer and inner limits' (2014) 51(2) Common Market Law Review 1-40; J. Basedow (ed.), Private Enforcement of EC Competition Law, Alphen aan den Rijn 2007; D.A. Crane, 'Optimizing Private Antitrust Enforcement' (2010) 63 Vanderbilt Law Review.

${ }^{3}$ In the last decade, Georgia implemented a number of bold and ambitious reforms and attained impressive achievements in many areas. Its position has been continuously improving in numerous international rankings and indexes including: the World Bank's Doing Business Index, the Heritage Foundation and the Wall Street Journal Index of Economic Freedom, the Transparency International Corruption Perception Index, and the Fraser Institute Economic Freedom of the World Index. See: M. Saakashvili, K. Bedukidze, 'Georgia, the Most Radical Catch-up Reforms' [in:] A. Aslund, S. Djankov, (eds.), The Great Rebirth: Lessons from the Victory of Capitalism over Communism, Washington, DC 2014, p. 149-164; N. Morari interview with K. Bendukidze, There Is Only One Way - Building a Free Economy, Ekho Kavkaza, 07.12.2009, p. 1; V. Papava, Economic Reforms in Post-Communist Georgia: Twenty Years After, New York 2012.

4 'Georgian politicians will share their experience of reforms with Ukrainians', Kyivpost, 08.12.2014; L. Rekhviashvili, 'Exporting Georgia's anti-corruption reforms to Ukraine: What 
Georgian competition policy. Not much has been written in academia to analyse the chain of illogical, sporadic and controversial reforms in this field ${ }^{5}$. Hence, this section briefly reviews Georgia's unusual evolutionary process, in order to explain why it is only now that the country is taking its first steps in competition law enforcement, even though it has already a two decades-long history in this field. This historic analysis will make it possible to clarify the particularities of the Georgian system.

As a former Soviet member state, Georgia has not inherited any valuable legal heritage on competition and market regulation. Centrally-planned Soviet economy did not function according to free market rules, the State kept an absolute monopoly over the production and distribution process ${ }^{6}$, there was no private ownership and property was seen as robbery ${ }^{7}$. Market competition was considered to be evil and was artificially substituted by socialist emulation ${ }^{8}$.

After living under the Soviet regime for 70 years, Georgia entered the unknown world of market economy after gaining independence in 1991. It was one of the first countries among the former Soviet Union and Eastern Block members to introduce antimonopoly legislation already in 1992. Despite the challenges of the transitional period, military conflicts and the economic collapse of the country ${ }^{9}$, the initial phase of the development of Georgia's

makes them worth replicating?', LeftEast, 03.04.2015; G. Lomsadze, E. Owen, 'Ukraine Wants to Pick Georgia's Brain on Reforms', Eurazianet, 27.05.2014; E. Livny, 'Lessons Learned From a Decade of Georgian Reforms. View From The Sky', ISET economist, 17.04.2015.

5 K. Lapachi, Competition Policy and Sectorial Regulation in Georgia, Tbilisi 2012.

${ }^{6}$ K.J. Cseres, Competition Law and Consumer Protection, the Hague 2005, p. 166-167; D.L. Prychitko, 'Marxism' [in:] The Concise Encyclopaedia of Economics, available at http:// www.econlib.org/library/Enc/Marxism.html (accessed 06.11.2015).

7 'Private property is robbery, and a state based on private property is a state of robbers, who are fighting for a share of the spoils', V.I. Lenin, Collected Works, see 'Speech Delivered at a Conference Of Chairmen Of Uyezd, Volost And Village Executive Committees Of Moscow Gubernia October 15, 1920', available at https://www.marxists.org/archive/lenin/works/1920/ oct/15b.htm (accessed 06.11.2015).

8 Various artificial stimulators were engaged in the Soviet Union in order to ensure some level of quasi competition and increase labour productivity (all-union socialist competition race, introduction of the titles of shock workers, shock brigades, transferable red banners and so forth). See T. Maximova-Mentzon, The Changing Russian University: From State to Market, Abingdon, 2013, p. 173; A. Nove, An Economic History of the U.S.S.R., Harmondsworth 1969, p. 208-209; K. Marx, The Poverty of Philosophy, Chapter Two: 'The Metaphysics of Political Economy' Section 3: 'Competition and Monopoly', first published in Paris and Brussels in 1847, available at https://www.marxists.org/archive/marx/works/1847/poverty-philosophy/ (accessed 06.11.2015).

${ }^{9}$ Instead of a gradual transition, Georgia experienced a 'shock therapy' after the Soviet Union disintegrated. Due to military conflicts, rampant criminality, inefficient governance and losing traditional trade and economic ties, Georgia scored a world record in economic decline during 1991-1994; its GDP fell up to 77\%, inflation reached $1500 \%$, and unemployment 
legal and institutional framework was relatively successful ${ }^{10}$. By 1996, Georgia already had the Law on Monopoly Activity and Competition ${ }^{11}$ and a functioning Antimonopoly Service ${ }^{12}$. In 1999, the effectiveness of Georgian antimonopoly service was studied and assessed positively by the European Bank for Reconstruction and Development ${ }^{13}$. Yet since the beginning of the new millennia, the development process was reversed, only to pave the way for a fragmentation and limitation of the competences of the Antimonopoly Service ${ }^{14}$. This new trend was not only against positive experiences and tendencies predominant elsewhere in the world, but against Georgia's own obligations deriving from international agreements ${ }^{15}$, such as the Partnership and Cooperation Agreement (hereafter, PCA) signed with the EU in $1996^{16}$.

Significant political developments took place in Georgia in 2003 and with them a new political power was brought into the government ${ }^{17}$. The new leadership launched a massive reformation process $^{18}$ which included, most importantly here, market liberalization. The aim of the reform was to diminish corruption risks, attract direct foreign investments and strengthen the national economy ${ }^{19}$. From then on, a decade of transformation started

increased dramatically. See: M. Saakashvili, K. Bedukidze, Georgia...; W. Shoemaker, Russia and The Commonwealth of Independent States, Lanham 2014, p. 236; L. King, G. Khubua, Georgia in Transition: Experiences and Perspectives, Frankfurt am Main 2009; T. Burduli, Economic Transition in Georgia: On the path from Shock Therapy toward DCFTA, Natolin 2014.

10 K. Lapachi, N. Kutivadze, The Institutional Framework for Competition Regulation in Georgia, EUGBC 2015, p. 18.

11 Parliament of Georgia, Law of Georgia of 25 June 1996, No. 288 on Monopoly Activity and Competition.

12 President of Georgia, Edict of 28 December 1996, No. 848 on the Antimonopoly Authority within the Structure of the Ministry of Economy of Georgia.

13 European Bank for Reconstruction and Development, Transition Report, London, 1999, p. 132-145.

${ }^{14}$ S. Fetelava, The Evolution of the Competition Theory and Antimonopoly Regulation in Georgia, Tbilisi, 2008, p. 20-22.

15 K. Lapachi, N. Kutivadze, The Institutional..., p. 18.

16 Partnership and Cooperation Agreement between the European Communities and their Member States, of the one part, and Georgia, of the other part - Protocol on mutual assistance between authorities in customs matters, 1996.

17 For more information see: http://news.bbc.co.uk/2/hi/4532539.stm (accessed 06.11.2015); L. Mitchell, Uncertain Democracy: U.S. Foreign Policy and Georgia's Rose Revolution, Philadelphia, 2011, p. 115; C. Sudetic, The Philanthropy of George Soros: Building Open Societies, New York 2011, p. 33-35; W. Shoemaker, Russia..., p. 238, 239; E. Svante, S. Cornell, F. Starr, The Guns of August 2008, Armonk-London 2009, p. 85-104.

18 M. Saakashvili, K. Bedukidze, Georgia..., p. 150.

19 The mastermind of the Georgian economic reform - Kakha Bendukidze (former Minister of Economy and the Minister for Reform Coordination between 2004 and 2008) saw market regulators as an unnecessary barrier and burden for doing business. For more information see: 'Godfather of Georgia's reforms dies at 58', Associated Press, 14.11.2014; N. Emerick, 
concerning the Georgian market which took place under the laissez-faire $\operatorname{slogan}^{20}$.

In 2005, a new law was adopted repealing Georgia's earlier antimonopoly legislation and shutting down the Antimonopoly Service ${ }^{21}$. The act was nominal, not even defining basic competition law terms such as: the relevant market, dominant position, significant market share and so forth. A new State agency was created but its existence was merely formal (a mere 5-6 members of $\operatorname{staff}^{22}$ ) with competences limited to state aid issues only ${ }^{23}$.

The condition of the Georgian market worsened after 2005 which, in truth, has always been far from a healthy competitive environment. The country moved towards an economy dominated by monopolies ${ }^{24}$ and oligopolies, which started to form on markets for the most commonly-used goods and services ${ }^{25}$. The share of small and medium sized enterprises in the Georgian market's total turnover decreased by more than $50 \%$ compared to $2000^{26}$. Georgia's positions fell in international rankings and indexes regarding market competition and antimonopoly regulation ${ }^{27}$. Unsurprisingly, a number of Georgian scholars expressed their criticism and concerns regarding these 'market liberalization' reforms ${ }^{28}$.

The Georgian government was forced to take steps against its own political will, when the EU mission highlighted in 2009 the need to improve Georgia's

G. Jandieri, 'Rose Revolution Shows the Results of Freeing Markets', 13.11.2013, http://www. bdlive.co.za/opinion/2013/11/13/rose-revolution-shows-the-results-of-freeing-markets (accessed 06.11.2015); 'A Different Sort of Oligarch', The Economist, 29.07.2014; N. Morari interview with K. Bendukidze, 'There Is...', p. 1.

${ }^{20}$ Laissez-faire theory strongly opposes any governmental intervention into business affairs. The economic concept of Laissez-faire, laissez-passer (translates as: let do, let pass) originated in the Physiocratic movement in France and is attributed to Vincent de Gournay. This doctrine laid the foundation for Adam Smith's Invisible Hand theory.

21 Parliament of Georgia, Law of Georgia of 3 May 2005, No. 1550 on Free Trade and Competition.

${ }^{22}$ K. Lapachi, N. Kutivadze, The Institutional..., p. 30.

23 Transparency International Georgia, Competition Policy in Georgia, Tbilisi 2012, p. 11.

${ }^{24}$ L. Papava, Georgia's Socio-Economic Development: Prospects over the Medium Term, 16.12.2012, available at http://www.international-alert.org/blog/socio-economic-developmentenglish (accessed 06.11.2015).

25 Transparency International Georgia, Competition Policy in Georgia, Tbilisi 2012.

26 National Statistics Office of Georgia, Statistics on the Operation of Undertakings, 03.09.2014, available at http://www.geostat.ge/cms/site_images/_files/georgian/business/Press\%20 Release\%202014_II.pdf, (accessed: 06.11.2015)

27 K. Lapachi, N. Kutivadze, The Institutional..., p. 28.

28 K. Lapachi, M. Tivishvili, 'Georgia' [in:] Competition Regimes in the World - A Civil Society Report, Jaipur, 2006, p. 384; S. Fetelava, The Evolution..., p. 22; K. Lapachi, N. Kutivadze, The Institutional..., p. 27. 
competition policy system ${ }^{29}$. As a priority area for the successful completion of the Deep and Comprehensive Free Trade Agreement (hereafter, DCFTA), the government was obliged to follow EU recommendations. Eventually, a Comprehensive Strategy on Competition Policy was issued in $2010^{30}$ and a new Law on Free Trade and Competition (hereafter, LFTC) adopted in May 2012. Although the steps taken at that time were significant, they were not a genuine reform but merely a formal reaction to the demands of the EU. The competences of the public enforcer were strictly limited by governmentdetermined priorities, making it ineffective and putting its impartiality into question. Moreover, the level of the de minimis threshold was set too high and the law lacked, among other things, the most effective public enforcement instrument against cartels - a leniency programme ${ }^{31}$. Despite the nominal nature of the reform, the LFTC actually created the first legal possibilities for private actions ${ }^{32}$.

The LFTC of 2012 was further amended in March 2014. Not only was the act renamed as the Law on Competition (hereafter, LC) ${ }^{33}$, the changes were so massive that the parliament practically adopted a new statute. The amendments solved a number of problems associated with the earlier LFTC and brought Georgian competition law in line with EU standards ${ }^{34}$. Shortly after, a new and independent Competition Agency (hereafter, the Agency) was formed ${ }^{35}$. The Agency did not start to function until mid November 2014 and it mostly issued minor decisions in its first year of functioning. All this changed in July 2015 when the investigation of the car fuel commodity market was completed. The Agency imposed fines on five major economic

${ }^{29}$ M. Maliszewska (ed.), Economic Feasibility, General Economic Impact and Implications of a Free Trade Agreement between the European Union and Georgia, Center for Social and Economic Research, 2008, p. 83-84.

30 Government of Georgia, Decree of 3 December 2010, No. 1551 on the Approval of the Comprehensive Strategy in Competition Policy.

${ }^{31}$ K. Lapachi, N. Kutivadze, The Institutional..., p. 30-31; N. Kutivadze, E. Anderson, TI Georgia recommendations for the Parliament on competition policy, 22.01.2013, available at http://www.transparency.ge/en/blog/recommendations-for-the-parliament-on-competition-policy (accessed 06.11.2015).

32 Alongside other grounds, this law was used by cargo companies to take action against the Ministry of Finance and Revenue Service for creating the monopoly of a state-owned company. For more information see: Transparency International Georgia, New draft law on Postal Service: Establishing the Georgian Post monopoly? 04.03.2014, available at http://www.transparency.ge/ en/node/3990 (accessed 06.11.2015).

33 Supra note 1.

${ }^{34}$ K. Lapachi, N. Kutivadze, The Institutional..., p. 32-36.

35 Government of Georgia, Ordinance of 14 April 2014, No. 288 on Adopting the Charter of LEPL Competition Agency. 
agents $^{36}$ totalled 55 million GEL (equivalent to about 22 million EUR at that time) - an unprecedented amount for Georgia ${ }^{37}$. Unlike public enforcement, which has become quite active in the last year, not much has happened in the field of private enforcement. The following section will discuss how badly does the Georgian market need an effective and well-functioning private enforcement system as well as what legal tools are currently provided for this purpose by Georgian law.

\section{Necessity for private enforcement of competition law in Georgia}

Since the early 1990s, Georgian antimonopoly, and later competition law, has always been developing toward its approximation with EU law ${ }^{38}$ - both the current LC as well as the Agency are constructed according to the EU model $^{39}$. It is a well-known fact that public enforcement has traditionally played the leading role in the EU competition law system. Yet an important additional trend developed, mostly over the last decade, of actively encouraging private enforcement of EU competition law. Despite its usual recourse to EU examples, Georgia does not follow the latter trend.

The question whether private enforcement should be actively used in Georgia also is related to the rationale and objectives of private enforcement itself. State institutions are generally granted 'public' enforcement powers, as competition distortions are against public interests, and effective enforcement by a competition authority is meant to protect this very interest ${ }^{40}$. However, public interests do not exist in isolation - they are not completely separate from private interests. Competition violations, in addition to distorting the market, cause harm to private rights of consumers and interests of other

36 Georgian law uses the term 'economic agent' in an analogue manner to the term 'undertaking' in EU Law. See Article 3(a) LC.

37 For detailed information see: http://competition.ge/images/upload/Annotation $\% 20$ in $\% 20$ English.pdf (accessed 06.11.2015).

38 Approximation with EU acquis has been a declared goal of all EU-Georgian agreements including: Georgia \& EU Partnership and Cooperation Agreement, 1996, Article 44; Association Agreement between the European Union and the European Atomic Energy Community and their Member States, of the one part, and Georgia, of the other part, Chapter 10. However, in practice, Georgian law has not always been on the track of EU harmonization.

39 Dechert LLP, Georgia's Competition Agency is a reality, 01.12.2014, available at http:// www.lexology.com/library/detail.aspx?g=6fab2551-b797-4936-b7c5-536ec166b7dd (accessed 06.11.2015).

${ }^{40}$ N. Bučan Gutta, The Enforcement..., p. 24; C. Harding, J. Joshua, Regulating Cartels in Europe. A Study of Legal Control of Economic Delinquency, Oxford 2003, p. 239. 
economic agents ${ }^{41}$. Even successful public enforcement (fining the infringers) does not heal the harm and damage experienced by the actual victims of the violation. It is therefore wrong to grant exclusive enforcement rights to a single (public) body. A healthy system is far more likely to develop if private parties are allowed to take actions as well ${ }^{42}$.

Private enforcement serves public interests because of its deterrence effects ${ }^{43}$. Taking into consideration that Georgian legislation sets a lower antitrust fine level than that applicable in the $\mathrm{EU}^{44}$, developing an effective private enforcement system is thus desirable in order to ensure a higher deterrence level. The need for an effective private enforcement model is increased by the fact that Georgia lags significantly behind when it comes to consumer protection. In fact, Georgia does not currently have an effective consumer protection system ${ }^{45}$. Although it is not the principal role of competition law to substitute for consumer protection, consumers are the ultimate beneficiaries of competition law. The development of an effective private enforcement system can thus empower Georgian consumers to intensify their role on the market.

In order to delineate the potential of private enforcement, the fact should be taken into account that the Georgian market has operated for a decade without any effective State regulation, and there are numerous signs of anti-competitive practices ${ }^{46}$. It can be presumed that there is a multitude of economic agents, the interests of which have been violated, which deserve to be granted legal tools to defend themselves. It might seem paradoxical that there are currently few claims for damages in Georgia. Yet this can be explained by the fact that the new legislation is still fresh and, in the absence of developed public enforcement practice (case law), stand-alone private enforcement cases are less likely. Among the few decisions issued by the Agency so far, no

${ }^{41}$ L.A. Velasco San Pedro et al (eds.), Private Enforcement of Competition Law, Valladolid 2011, p. 51.

42 J. Basedow, supra note 2 at p. 8.

43 N. Bučan Gutta, The Enforcement..., p. 26; B. Rodger, A. MacCulloch, Competition Law and Policy in the EU and UK, London-New York 2014, Chapter 2 'Administrative Enforcement in UK', subsection 'Settlement'.

${ }^{44}$ Georgian law allows fining the infringer with an amount of no more than $5 \%$ of its annual turnover.

45 The market deregulation wave also neutralized consumer protection in Georgia. When the EU spoke against poor food safety regulations, the Georgian government used this recommendation to reform this field, only in order to adopt a new law regarding food safety, eventually abolishing existing consumer rights' protection law in 2012. L. Todua, Who is protected by the Georgian government - entrepreneur or the consumer? 15.12.2011, available at http://dfwatch.net/who-is-protected-by-the-georgian-government-\%E2\%80\%93-entrepreneuror-the-consumer-16054-2575 (accessed 06.11.2015).

46 Z. Gvelesiani, Need for Competition Law - Discussing the Case of Georgia, Yearbook of Antitrust and regulatory Studies 8(11), 2015, pp. 25-29. 
infringement by an economic agent has been detected yet, except on the car fuel commodity market. The latter decision is currently pending its judicial review and if the court upholds it, the victims of the infringement might feel more confident to submit private actions. In fact, cases of such high public interest increase consumer awareness - they attract the attention of consumers and businesses alike, and educate the society about the possibilities offered by this new legal field.

Practice and time will test the question if Georgia will follow the EU trend, or whether the future of its competition law enforcement will be exclusively shaped by the Agency. An analysis of Georgian competition legislation (the LC and other secondary acts ${ }^{47}$ ), leads to the conclusion that private enforcement is permitted. Yet a specific strategy does not exist for encouraging private enforcement, nor in fact for actually avoiding it in the initial phase in order to let the Agency assume the role of the 'enforcement driver'. This situation can be partially explained by the fact that the Agency is still very young and weighted down with numerous tasks - formulating a private enforcement strategy might not be one of its main priorities. However, after reviewing its action plan for 2014-201748, there is still no sign that the Agency is actually planning to take any steps in this context. This might give the impression that there is no clear understanding of the potential of private enforcement, and that its development is left to its own devices.

The only openly expressed position of the Agency regarding taking competition cases to courts is that judges might not be sufficiently prepared to effectively deal with cases based on the novel, for Georgia, field of competition law. As stated by the Agency, unqualified judges might become a burden for the effective performance of competition law ${ }^{49}$. Although the Agency stresses the need for the intensive competition law training of judges, it is yet unknown what actual activities are envisaged in this context. It is also unclear when Georgian judges are expected to be properly qualified to rule on competition law $\operatorname{cases}^{50}$.

47 Available at http://competition.ge/ge/page.php?p=4 (accessed 06.11.2015).

48 See http://competition.ge/ge/page2.php? $\mathrm{p}=1 \& \mathrm{~m}=14$ (accessed 06.11.2015).

49 Speech of A. Gugushvili - the First Category Adviser of the Competition Department (International Relations) of the Georgian Competition Agency, at the International Competition Network conference, held in Sidney from 28.04.2015 to 01.05.2015. For more information, see http://competition.ge/ge/page4.php?b=270 (accessed 06.11.2015).

50 The High School of Justice (HSoJ) is an educational institution, which works to institutionalize training for the judges and other court staff. According to the HSoJ website, 2 day training was held for 17 judges from the Tbilisi City Court and the Tbilisi Appellate Court regarding competition law in October 2014. There is no other information available regarding the continuous education of judges in this field. See: http://www.hsoj.ge/eng/media_center/ news/2014-12-11-treningi-temaze-konkurenciis (accessed 30.09.2015). 
Without developed jurisprudence, or the ability to identify specific enforcement trends in the Agency's case law, the only methodology possible to evaluate private enforcement perspectives in Georgia is to examine its existing legal rules and the availability of private actions. Knowing what the offered legal options are, and how easily accessible they seem, makes it possible to analyse what the key challenges might be for potential private enforcers. The next sections are dedicated to these issues.

\section{Availability of private enforcement of competition law infringements and damages claims}

According to Article $4 \mathrm{LC}$, the Agency is an independent legal entity of public law, responsible for the enforcement and protection of that Law. However, the Agency does not own the exclusive rights to enforce the LC there are various other possibilities of taking action without its involvement. Article 28(2) LC determines that in the case of a competition law violation, any person (natural or legal) is entitled to go directly to a court, without applying to the Agency first. Article 28(2) LC indicates that private claims must be lodged before the Tbilisi City Court giving the latter the exclusive jurisdiction to hear such cases.

The Georgian judicial system is divided into civil, administrative and criminal proceedings ${ }^{51}$. Civil cases include disputes between private parties, while administrative cases deal with disputes against State institutions. Article 28(3) LC makes it clear, albeit it does not state it explicitly, that Article 28(1) LC is applicable to civil disputes - it states that the court will declare the claim as inadmissible, or close an already admitted claim, if insolvency proceedings are opened against the respondent economic agent. From this it can be adduced that such disputes have a civil nature because insolvency proceedings can only relate to private entities, and not to State bodies (the latter are subjects of administrative law).

On the other hand, administrative proceedings might be necessary when private interests are violated by the State itself, mostly by granting unjustified aid to competitors and distorting the natural balance of the market. For such cases, Article 15 LC allows persons, whose interests have been violated, to appeal the state aid. Although Article $33 \mathrm{LC}^{2}$ is entitled 'The rule of appealing

51 Parliament of Georgia, Organic Law of Georgia of 8 December 2009, No. 2257 on Common Courts, Article 1(2); the term 'Organic Law' is a type of legal act within Georgian legal system that has a higher hierarchy than (ordinary) law and regulates the issues as provided by the Constitution of Georgia. See: Law of Georgia on Normative Acts Articles: 7(2), 7(3), 8). 
the decision of the agency', it contains rules of a broader nature. It states that in the case of a violation of competition related legislation (exceeding the scope of just the LC), any interested party can directly apply to the State body, or to the relevant official, or take an action to courts and claim damages.

After adopting the LC and recognizing certain anti-competitive actions as illegal, it is now possible to also use tort law in order to claim damages suffered due to competition law infringements. Tort law provisions are contained in chapter III of the Georgian Civil Code (hereafter, GCC). According to Article 992 GCC, a person who unlawfully causes damage to another shall compensate that damage. The GCC also establishes joint and several liability, which can be used against infringing parties of anti-competitive agreements and concerted practices. Liability is shared in full, which means that each defendant is deemed liable for the entire damage, regardless of the percentage of its own fault. Liability is shared among the instigators and accessories, as well as those consciously benefiting from the damage caused to another person ${ }^{52}$. It is clear that joint and several liability based on tort would apply to cartel members. However, this does not mean that each cartel participant will always be fined with an equal amount within the framework of public competition law enforcement. The Agency has the discretion to individually define fines imposed on each economic agent, taking into account the gravity and duration of the infringement and the damages caused ${ }^{53}$. Moreover, participation in the leniency programme can also lead to full or partial immunity.

According to the GCC, the limitation period on damages claims caused by tort is set to three years starting from the moment when the victim became aware of the damage or of the identity of the person liable ${ }^{54}$. However, the GCC also says that in the case of collision between norms of the same rank, the 'special' and/or 'newer' law applies ${ }^{55}$. The LC is 'newer' than the GCC as well as a 'special' act for competition regulation, hence its rules apply. In this context, it contains a stricter rule than the general provision of the GCC the $\mathrm{LC}$ restricts the limitation period to three years from the moment of the infringement ${ }^{56}$.

Decisions of the $1^{\text {st }}$ instance court can be appealed to the Appellate court $^{57}$. The ruling of the latter can be taken before the Supreme Court

52 Parliament of Georgia, Law of Georgia of 26 June 1997, No. 786, Civil Code of Georgia, Article 998.

53 Article 33(3) LC.

54 Article 1008 GCC.

55 Ibidem, Article 2(2).

56 Article 27 LC.

57 Parliament of Georgia, Law of Georgia of 14 November 1997, No. 1106, The Georgian Civil Procedural Code, 1997, Article 364 
(court of the highest and final instance in Georgia). However, the Supreme Court admits cases in exceptional cases only - that is - if assessing them is important for developing a uniform judicial practice, if the decision of the appellate court differs from precedents of the Supreme Court on analogous or essentially similar facts, or in case of a significant breach of procedural law that substantially affected the outcome of the case. As a rule, most complaints to the Supreme Court are dismissed as inadmissible.

With regard to collective actions, they are an unknown legal institution for Georgian law. The closest provision lays in the possibility of joint actions, determined by Article 86 of the Georgian Civil Procedural Code (hereafter, GCPC). A joint action may be lodged by a number of persons together, when the object of the lawsuit is their joint rights, or their claim is based on the same grounds. A joint action is also allowed when claims are similar, even if the previous two conditions are not fully met. However, it lays in the discretion of the judge to allow a joint lawsuit or divide it into several individual ones ${ }^{58}$. Each claimant of the joint lawsuit participates independently in the proceedings ${ }^{59}$. Hence, their claims can vary and eventually, the resulting judgements might differ depending on the claimant. However, claimants of a joint lawsuit are allowed to grant the power of attorney to one of them, or let the same lawyer represent them all ${ }^{60}$. Moreover, if the court discusses several cases similar to one another, the judge can join them ex officio or upon a petition of the parties $^{61}$.

In addition to ordinary courts, Georgian legislation allows one more possibility for private enforcement, which is limited to administrative cases only and does not directly award any damages compensation. It can, however, be used as an effective tool against competition distorting actions from administrative bodies, making it possible to claim damages as a result. Article 30(2) of the Constitution of Georgia determines that the State is bound to promote competition and prohibits monopolistic activity. The judicial body ensuring the supremacy of the Constitution is the Constitutional Court of Georgia $^{62}$ (hereafter, CCG). Any normative legal act issued by a State body can be appealed to the CCG in order to ascertain its compliance with the Constitution. This presents an effective legal tool to any person who believes that the rights and freedoms recognised under chapter II of the Constitution

58 Ibidem. Article 182, 203(c).

59 Ibidem, Article 86(d).

${ }^{60}$ Ibidem, Article 87(b).

61 Ibidem, Article 182(4).

62 Parliament of Georgia, Organic Law of Georgia of 31 January 1996, No. 95 on the Constitutional Court of Georgia, Article 1. 
of Georgia ${ }^{63}$ have been violated or might be directly violated. Although the CCG does not grant compensation, its decision can be used in follow-on cases taken before ordinary courts in order to claim damages. The ruling of the CCG can be used as proof of competition restriction and illegal aid by a State body. This legal tool has already been used by cargo companies. Although the case was ultimately closed, because the disputed act was repelled by the issuing body itself ${ }^{64}$, it established a good example of how the CCG might serve the interests of private enforcement.

\section{Challenges for the development of an effective private enforcement system}

Reviewed in the previous section were the possibilities of private enforcement in existing Georgian legislation. As demonstrated, any interested person has the right to take an action to the courts and claim damages. However, there are various challenges and barriers that discourage individuals from taking private actions. For Georgia to have an effective private enforcement system, certain developments are necessary. The current system has to be made more accessible in order to turn damages claims into common practice (instead of exceptions). This would give them a proper deterrence effect and enable them to support competition policy in achieving its overall goals.

This section examines barriers to the development of private actions. Due to size constrains however, the analysis will focus on problems specific to Georgia. A number of traditional challenges related to private enforcement will thus be omitted, which are common for all jurisdictions. These include: issues of legal standing and indirect enforcement, burden of proof, calculating damages, access to materials, litigation costs and so forth ${ }^{65}$.

${ }^{63}$ Chapter Two, Citizenship of Georgia; Fundamental Human Rights and Freedoms (covers social economic rights, including Article 30 which guarantees that the State should promote competition).

${ }^{64}$ From January 2013, the market of cargo services became a subject of State interference, attempting to let the State-owned Georgian Post monopolize the market. The victimized companies applied to the court, demanding the abolition of the disputed acts. After losing the case, the government adopted a new resolution, this time attempting to monopolize entire postal services market. The resolution was appealed to the CCG. The Court admitted the case, but before hearing it, the government cancelled the appealed resolution. Eventually, the company filed a civil lawsuit, asking for damages in the amount of 1500000 GEL (equivalent to 632191 EUR) from the State. For more information see: Transparency International Georgia New draft law...

65 Supra note 2. 
One of the biggest barriers for bringing a private action in a competition case in Georgia is the specific limitation period established in Article 27 LC, which provides for a statute of limitation of three years from the date of the infringement. As mentioned, this rule departs from the general rule applicable to damages claims set out in the GCC, where the three year period runs from the moment when the victim becomes aware of the damage or of the identity of the perpetrator. This means that for competition law infringements, the victim might miss the deadline even without knowing that the time limit is running. While anti-competitive conducts are often secret in nature, private parties do not have any special powers ${ }^{66}$ (unlike public enforcement agencies) and might find it hard to detect them on their own. As Bučan Gutta rightfully indicates, antitrust victims are often not even aware of the existence of an infringement, or might learn about it only long after it took place. Starting to count the limitation period as early as the date of the infringement means that the actual time for taking action is much shorter, or does not even exist, at least in some cases ${ }^{67}$. The time limit established by the LC goes against modern practice and is based on a model rejected 30 years ago by the European Court of Justice ${ }^{68}$. Private competition law enforcers would thus benefit from the application of the general rule set out by the GCC - not only would they have more time to act, but it would also help them fulfil their burden of proof ${ }^{69}$. Overall, the motivation behind setting in the LC of a special, shorter time limit for competition law cases is neither clear nor justifiable. In practice, this provision might become a significant barrier to the development of private enforcement in Georgia - in certain cases, it might deprive an injured person from the right to bring a claim and get compensation ${ }^{70}$.

Article 28(2) LC states that claims regarding the LC are to be lodged exclusively with the Tbilisi City Court. This provision is clearly restrictive and limits the 'right to apply to the court for protection of [...] rights and freedoms' guaranteed by Article 42(1) of the Constitution of Georgia. The official motivation behind this rule is given in the relevant Governmental Strategy prepared in 2010. The document states that 'the main reason for this decision ... is to safeguard the building up of relevant competence as well as a uniform application and case law in the field of competition law'71. The justification and

${ }^{66}$ K. Hüschelrath, S. Peyer, Public and Private Enforcement of Competition Law a Differentiated Approach, ZEW Discussion Paper No. 13-029, Mannheim 2013, p. 6.

67 N. Bučan Gutta, The Enforcement..., p. 270.

68 Cases 145/83 and 53/84 Stanley George Adams v. Commission [1985] ECR 03595.

${ }^{69}$ If the moment when the victim became aware of the damage is disputable, the burden of proof lies on the defendant, as ruled by the Supreme Court of Georgia. See decision of the Supreme Court of Georgia of 28 May 2014, No. AS-260-244-2014.

70 N. Bučan Gutta, The Enforcement..., p. 270.

71 Supra note 30, p. 31. 
proportionality of such an approach are controversial. Even if it is assumed that the number of competition cases will be limited in Georgia, without the practical need to let all $1^{\text {st }}$ instance courts deal with them, it does not seem proportional to restricting an individual's right to file a claim to a single court only. Providing exclusive jurisdiction over competition law cases to a single court, effectively monopolizing its competences, is not in line with the decentralization trend followed by EU law since $2003^{72}$. With regard to the justification for using this particular measure in order to develop a uniform enforcement practice and jurisprudence in this field, it is hardly the role of a single $1^{\text {st }}$ instance court to develop such uniformity, especially by way of technically restricting all other courts from reviewing such cases. As clearly determined by Article 391 of the Civil Procedural Code of Georgia, the Supreme Court is responsible for developing uniform jurisprudence and there is no need to assign this function to lower instance courts for specific legal branches.

The abovementioned Governmental Strategy indicated also that there was a need for judges to be trained in order to enhance their knowledge and qualification in this field ${ }^{73}$. The same view has later been repeated by representatives of the Agency ${ }^{74}$. It is clearly easier and faster to train the judges of a single court than the entire national judiciary. However, this justification would have been valid if the restrictions were only temporary. It is clear that neither the government nor the Agency distrusts judges in general, yet they both indicated the need for certain preparatory works to take place in the initial enforcement phase. It is fair to say therefore that this is a temporary problem which should be duly resolved. Unfortunately, the legal provision that gives exclusive jurisdiction to the Tbilisi City Court is not transitional in nature, and it is not expected to expire, unless the LC is amended.

When it comes to competition law cases, the necessity to have specialized judges is not disputable ${ }^{75}$. However, even if the goal of this restriction was to avoid training the entire national judiciary, it is not a proportional measure. It would have been fairer to keep a geographical balance and, along with the Tbilisi City Court, assign competition cases to at least one court in west

72 Council Regulation 1/2003 of 16 December 2002 on the implementation of the rules on competition laid down in Articles 81 and 82 of the Treaty, OJ L 1, 04.01.2003, p. 1.

73 Supra note 30, p. 31.

${ }^{74}$ For more information, see: http://competition.ge/ge/page4.php?b=270 (accessed 06.11.2015).

75 In $1^{\text {st }}$ instant courts, judges specialize in narrow fields in order to ensure their qualification and reduce the duration of proceedings. See: http://www.supremecourt.ge/court-system/aboutsystem/ (accessed 06.11.2015); Parliament of Georgia, Organic Law of Georgia of 8 December 2009, No. 2257 on Common Courts, Article 30. 
Georgia, analogue to the appellate court system ${ }^{76}$. Moreover, the assigned court is not in fact a special court (as it is in certain EU Member States ${ }^{77}$ ) but an ordinary $1^{\text {st }}$ instance court merely situated in the country's capital.

Georgia has in fact 26 separate $1^{\text {st }}$ instance district or city courts, distributed across the entire country. It is clear that having several courts in each region serves the goal of making the judicial system easily accessible for every person. Tbilisi is without a doubt the biggest city in Georgia - it has the largest population and almost $50 \%$ of businesses are registered here ${ }^{78}$. However, a huge number of consumers live outside Tbilisi and a number of businesses are active in its various geographic regions ${ }^{79}$. Considering that Georgia is a relatively small size country, limiting jurisdiction to a single court only might not be an insuperable obstacle. Yet it can still be a major barrier, especially for consumers living outside Tbilisi, as using a centralized court would require additional financial and logistical expenditures. The chosen solution is also questionable considering the issue of discrimination according to the geographical location of the claimant. Not only is eliminating discrimination a goal of the LC, non-discrimination is an explicitly declared principle to be complied with by the Agency when performing its duties.

A further problem must be identified related to granting exclusive jurisdiction over competition cases to the Tbilisi City Court - the latter is already one of the most overloaded courts in Georgia. As stated in an interview by its Chair, the Tbilisi City Court is already working at its maximum capacity, and yet it cannot deal with its current caseload. It neither has enough judges, nor court rooms ${ }^{80}$. According to statistical data quoted by the Chair, each of its judges hears between 40-70 cases a month, while some have more than 300 cases

76 Georgia is geographically divided into its west and east parts by a mountain range. Tbilisi is situated in the central part of east Georgia and therefore is less accessible for the resident of west Georgia. Georgia has two appellate courts, one situated in Tbilisi and another in Kutaisi, the second largest city, located in central west Georgia. The same model could have been used for competition law cases, which would have been a better solution from the point of view of fairness and equal accessibility to courts.

77 For instance, the Polish Court of Competition and Consumer Protection (SOKiK) is a special court working exclusively on the issues of competition and consumer laws.

78 According to the data of the Population Census of Georgia 2014, 3729635 person lives in Georgia - 1118035 out of them reside in Tbilisi; For more information, see the preliminary results of the Population Census of Georgia 2014: http://geostat.ge/cms/site_images/_files/ georgian/population/agceris\%20cinascari\%20shedegebi_30.04.2015.pdf (accessed 06.11.2015). Furthermore, in Georgia, $43.4 \%$ of all businesses are registered in Tbilisi see: http://geostat. ge/?action $=$ page \&p_id=241\&lang=geo $($ accessed 06.11 .2015$)$.

79 When the competition agency was launched, all of the early applications were filed by companies operating in regions other than Tbilisi.

80 See: http://www.kvirispalitra.ge/justice/23403-ratom-tcianurdeba-saqmeebis-gankhilvasasamarthloshi.html (accessed 06.11.2015). 
assigned to them. At this point in time, the court is hearing cases that have been lodged two years ago. In such an environment, it is hard for the judges to even only deal with regular cases. The specific and innovative nature of competition law cases would make this matter far worse, especially considering that the Tbilisi City Court is expected to develop uniform jurisprudence in this new legal branch. In order to do so, its judges would have to ensure a higher than usual quality of their (competition-related) decisions. This expectation is in stark opposition to the recently criticised 'conveyer-belt' type of system, which the Tbilisi City Court is said to be currently employing. According to Transparency International Georgia, when rendering their decisions, judges have sometimes failed to be well acquainted with their own cases; they were also said to be more interested in closing a case as fast as possible, than in delivering justice ${ }^{81}$.

Another challenge concerns Georgia's litigation culture and traditions. As Paulis states ${ }^{82}$, radical differences exist between Europeans and Americans in their attitude to courts. In the US, the court is a place where individual go to solve their problems; there is a belief that the judge will help defend recognized rights. In Europe, courts are viewed as the last resort - a place, most want to avoid. It is fair to say that courts have never been popular in Georgia, nor were they ever seen as a trustworthy ally. The Georgian judicial system has always been weak. It suffered from corruption in its earlier years and from strong political pressures in the last decade ${ }^{83}$. Trust towards courts has never been high ${ }^{84}$ - surveys repeatedly demonstrated that the majority of the Georgian society did not see the courts as independent, and had only limited trust in the judicial system ${ }^{85}$. The newest survey proves that there is still a strong negative attitude toward the judicial system in Georgia, and

81 Transparency International Georgia, Court Monitoring Report of Administrative Cases, Tbilisi 2012, p. 29.

82 The speech delivered at the Max Planck Institute for Comparative and Private International Law on 7 April 2006, for transcript see: J. Basedow, Private..., p. 7-16.

83 S. Jones, War and Revolution in the Caucasus, Abingdon 2010, p. 152; S. Jones, Georgia: A Political History Since Independence, London 2015, p. 132; Freedom House, Nations in Transit 2010: Democratization from Central Europe to Eurasia, Lanham 2010, p. 214. Also see: https://freedomhouse.org/report/countries-crossroads/2006/georgia\#.VVsPofmqqko (accessed 06.11.2015).

84 Personal experience, from the time working at the Transparency International Georgia's Advocacy and Legal Advice Centre (ALAC), makes it possible to recall numerous cases when victims of various legal violations were hesitant to take formal legal actions and instead insisted on sending a letter to totally unrelated officials (such as the President, Prime Minister, Chair of the Parliament) and State bodies, hoping for their assistance.

85 Caucasus Research Resource Centres, Attitudes to the Judiciary in Georgia: Assessment of Legal Professionals and Business Leaders, June 2012, p. 6, http://www.crrc.ge/uploads/files/ research_projects/JILEP_Report_12_July_2012_ENG.pdf (accessed 06.11.2015). 
that reforms in this area are among the least successful ones. The majority of the population has a negative or no opinion about the performance of the courts $^{86}$. Private enforcement is a judicial remedy, unlike self-help where a victim acts independently without the intervention of a court ${ }^{87}$. The quality and effectiveness of private enforcement depends therefore on the strength and independence of the judiciary and other enforcement institutions ${ }^{88}$. Hence, trust toward judicial institutions plays a significant role in the context of private competition law enforcement - its lack can become a major barrier for private parties who might have suffered harm from an anti-competitive practice, but remain nevertheless reluctant to approach the courts for help.

It is not a secret that Georgia has a long road ahead to create an impartial and efficient judicial system. It is also necessary to raise awareness and educate the society about the basic legal procedures and principles, since knowledge is noticeably lacking ${ }^{89}$. The Governmental Strategy spoke of working with the private sector in order to raise awareness, as part of the operational programme for competition policy ${ }^{90}$. The need to educate businesses is even more prominent, considering that the government spend most of the last decade trying to persuade them that leaving the market without state intervention (without competition law) was in fact in their interest ${ }^{91}$. Eventually, when market regulation was reintroduced, there was some scepticism among the businesses toward the reform ${ }^{92}$.

The issue of the burden of proof remains a typical challenge for private enforcers in every jurisdiction. It might prove particularly difficult in Georgia, however, considering its lack of jurisprudence or developed case law (which claimants could use to support their arguments), making it necessary for private parties to interpret the LC themselves. The problem could be remedied by partial reliance on the rich EU jurisprudence. However, not only does the latter not apply to Georgia directly, it might often not be relevant either. Still, it can be a helpful guide for at least some cases. According to Article 7(5) of the

86 International Republican Institute, Public Opinion Survey Residents of Georgia, February 3-28, 2015, http://www.iri.org/sites/default/files/wysiwyg/iri_georgia_public_2015_final_0.pdf (accessed 06.11.2015).

87 E.M. Kieninger (ed.), Security Rights in Movable Property in European Private Law, Cambridge 2004, p. 79.

${ }^{88}$ G. Kochendörfer-Lucius, B. Pleskovic (eds.), Investment Climate, Growth, and Poverty, Washington, DC 2005, p. 36.

89 Supra note 84, p. $14-16$.

90 Supra note 30, p. 40.

91 N. Morari interview to K. Bendukidze, 'There Is...', p. 1, supra note 3. See also: http://www. tabula.ge/en/story/89804-famous-reformist-kakha-bendukidze-dies-at-58 (accessed 06.11.2015).

92 I. Lekvianidze, 'What an effective competition policy should be like?', Forbes Georgia, 13.02.2014. 
Law of Georgia on Normative Acts, every international agreement of Georgia that entered into force, takes precedence over domestic normative acts, unless it contradicts the Constitution of Georgia. All of the agreements that Georgia signed with the EU, including the PCA and the Association Agreement, stress that Georgia will approximate its laws with EU acquis ${ }^{93}$. The latter term has a wide interpretation including EU jurisprudence ${ }^{94}$. Moreover, even if EU jurisprudence is not directly binding in Georgia, it is very relevant for the Georgian model, which was constructed according to the EU one. Maus refers to this phenomenon as a 'dialogue of judges', which concerns the confirmation, elaboration or rejection of the jurisprudence of foreign countries or supranational courts ${ }^{95}$. In the absence of national jurisprudence, reliance on foreign best practices, and the interpretations given by famous judges, should not be harmful. Therefore, while training Georgian judges, it is important to educate them on EU jurisprudence, in order to make them more open for sharing argumentations based on EU rulings and let them understand and interpret the referred cases correctly.

\section{Conclusions}

The re-introduction of competition law in Georgia was one of the most important legal developments of recent years. Since its adoption in 2012, Georgia's Law on Competition has been subject to major amendments and has progressed significantly. Despite several remaining criticisms, the positive impact of the recent reform cannot be denied. After years of an unregulated market, Georgia has now a modern competition law act and a functioning competition authority. Private parties are granted certain legal guarantees and mechanism to defend themselves and to claim damages.

Still, there are a number of challenges which need to be overcome in order to ensure that the recent legal changes will have a noteworthy impact in practice. The paper indicated some of the problems, which can be solved either by legal amendments or, in certain cases, by a more comprehensive and systematic change. It is necessary to generate a clear strategy about private enforcement and take further measures (beyond legal changes) to practically

\footnotetext{
93 Supra note 38.

94 See: http://europa.eu/legislation_summaries/glossary/community_acquis_en.htm (accessed 06.11.2015).

95 D. Maus, Application of the case law of Foreign Courts and Dialogue between Constitutional Courts, 2010, p. 8, available at http://ec.europa.eu/enlargement/policy/glossary/terms/acquis_ en.htm (accessed 06.11.2015).
} 
encourage victims to take actions, be more confident and less reluctant to act. The future will show how private enforcement will develop in Georgia, and what other problems will appear in practice. So far, Georgia has a promising starting point and with strong political will, developing an effective private as well as public enforcement system is possible, as well as extremely necessary.

\section{Literature}

Basedow J. (ed.), Private Enforcement of EC Competition Law, Alphen aan den Rijn 2007. Basedow J., Terhechte J.P., Tichý L., Private Enforcement of Competition Law, BadenBaden 2011.

Berglund M., Cross-Border Enforcement of Claims in the EU: History, Present Time and Future, Alphen aan den Rijn 2014.

Bučan Gutta N., The Enforcement of EU Competition Rules by Civil Law, AntwerpenApeldoorn-Portland 2014.

Burduli T., Economic Transition in Georgia: On the path from Shock Therapy toward DCFTA, Natolin 2014.

Crane D.A., 'Optimizing Private Antitrust Enforcement' (2010) 63 Vanderbilt Law Review.

Cseres K.J, Competition Law and Consumer Protection, the Hague 2005.

Cseres K.J., Mendes J., 'Consumers' access to EU competition law procedures: outer and inner limits' (2014) 51(2) Common Market Law Review.

Engstrom D.F., 'Private Enforcement's Pathways: Lessons from Qui Tam Litigation' (2014) 114(8) Columbia Law Review.

Fetelava S., The Evolution of the Competition Theory and Antimonopoly regulation in Georgia, Tbilisi 2008.

Freedom House, Nations in Transit 2010: Democratization from Central Europe to Eurasia, Lanham 2010.

Gvelesiani Z., 'Need for Competition Law - Discussing the Case of Georgia' (2015) 8(11) YARS 25-29.

Harding C., Joshua J., Regulating Cartels in Europe. A Study of Legal Control of Economic Delinquency, Oxford 2003.

Hüschelrath K., Peyer S., Public and Private Enforcement of Competition Law a Differentiated Approach, ZEW Discussion Paper No. 13-029, Mannheim 2013.

Ioannidou M., Consumer Involvement in Private EU Competition Law Enforcement, Oxford 2015.

Jones S., Georgia: A Political History Since Independence, London 2015.

Jones S., War and Revolution in the Caucasus, Abingdon 2010.

King L., Khubua G., Georgia in Transition: Experiences and Perspectives, Frankfurt am Main 2009.

Komninos A.P., EC Private Antitrust Enforcement, Decentralised Application of EC Competition Law by National Courts, Oxford-Portland 2008

Lapachi K., Competition Policy and Sectoral regulation in Georgia, Tbilisi 2012.

Lapachi K., Kutivadze N., The Institutional Framework for Competition Regulation in Georgia, EUGBC 2015. 
Marx K., The Poverty of Philosophy, Paris-Brussels 1847.

Maus D., 'Application of the case law of Foreign Courts and Dialogue between Constitutional Courts', 2010, available at www.constcourt.ge/en/ajax/downloadFile/1770.MaximovaMentzon T., The Changing Russian University: From State to Market, Abingdon 2013.

Milutinović V., The 'Right to Damages' under EU Competition Law: from Courage v. Crehan to the White Paper and Beyond, Alphen aan den Rijn 2010.

Mitchell L., Uncertain Democracy: U.S. Foreign Policy and Georgia's Rose Revolution, Philadelphia 2011.

Möllers T.M.J., Heinemann A., The Enforcement of Competition Law in Europe, CambridgeNew York 2007.

Nove A., An Economic History of the U.S.S.R., Harmondsworth 1969.

Papava V., Economic Reforms in Post-Communist Georgia: Twenty Years After, New York 2012.

Petrov R., Elsuwege P., Legislative Approximation and Application of EU Law in the Eastern Neighbourhood of the European Union: Towards a Common Regulatory Space?, Abingdon 2014.

Rodger B., MacCulloch A., Competition Law and Policy in the EU and UK, London-New York 2014.

Saakashvili M., Bedukidze K., 'Georgia, the Most Radical Catch-up Reforms' [in:] A. Aslund, S. Djankov (eds.), The Great Rebirth: Lessons from the Victory of Capitalism over Communism, Washington, DC 2014.

Shoemaker W., Russia and The Commonwealth of Independent States, Lanham 2014.

Sudetic C., The Philanthropy of George Soros: Building Open Societies, New York 2011.

Svante E., Cornell S., Starr F., The Guns of August 2008, Armonk-London 2009.

Van Bael I., Due Process in EU Competition Proceedings, Alphen aan den Rijn 2011.

Velasco San Pedro L.A. et al (eds.), Private Enforcement of Competition Law, Valladolid 2011.

Wils W.P.J., 'Should Private Antitrust Enforcement Be Encouraged in Europe?' (2003) 26(3) World Competition: Law and Economics Review. 